\title{
Kinerja Keuangan Perbankan Syariah: Tinjauan Dari Intellectual Capital Pada BNI Syariah
}

\author{
Hastuti Olivia $^{1}$, Gadis Arniyati Athar' ${ }^{1}$, Tia Andrianti Nasution' ${ }^{1}$, Syahrijal Hidayat ${ }^{2, *}$ \\ ${ }^{1}$ Program Studi Perbankan Syariah, STAI H. Abdul Halim Hasan Al Ishlahiyah, Binjai, Indonesia \\ ${ }_{2}^{2}$ Prodi Akuntansi, STIE Muhammadiyah Asahan, Asahan, Indonesia \\ Email: ${ }^{1}$ hastutiolivia@ ishlahiyah.ac.id, ${ }^{2}$ gadisarniyatiathar82@gmail.com, ${ }^{3}$ tianasution16@ gmail.com, \\ 4,*syahrijalhidayat528@gmail.com \\ Email Penulis Korespondensi: syahrijalhidayat528@gmail.com \\ Submitted: 17/11/2021; Accepted: 26/11/2021; Published: 30/11/2021
}

\begin{abstract}
Abstrak-Penelitian ini bertujuan untuk menganalisa pengaruh intellectual capital (IC) terhadap kinerja keuangan pada Bank Negara Imdonesia (BNI) Syariah. Hipotesis dalam penelitian ini diuji dengan menggunakan metode Structural Equation Modeling (SEM) yang berbasis varian atau Partial Least Square (PLS) dengan melibatkan beberapa variabel dari intellectual capital (IC) yang dimodifikasi untuk perbankan syariah yakni iB-VACA, iB-VAHU, iB- STVA. Hasil penelitian menunjukkan untuk iB-VAIC dan iBVACA berpengaruh terhadap kinerja keuangan. Sedangkan untuk iB-VAHU tidak berpengaruh terhadap kinerja keuangan, dan iBSTVA memiliki pengaruh negatif terhadap kinerja keuangan
\end{abstract}

Kata kunci: VAIC; VACA; VAHU; STVA; Kinerja Keuangan.

Abstract-This study aims to analyze the effect of intellectual capital (IC) on financial performance at Bank Negara Indonesia (BNI) Syariah. The hypothesis in this study was tested using the variant-based Structural Equation Modeling (SEM) method or Partial Least Square (PLS) involving several variables of intellectual capital (IC) modified for Islamic banking such as iB-VACA, iB-VAHU, iBSTVA. The results showed that iB-VAIC and iB-VACA) had an effect on financial performance. Meanwhile, iB-VAHU has no effect on financial performance, and iB-STVA has a negative effect on financial performance.

Keywords: VAIC; VACA; VAHU; STVA; Financial Performance

\section{PENDAHULUAN}

Perjalanan Perbankan syariah di Indonesia sangat penjang dimulai dengan dibentuknya Bank Perkreditan Rakyat Syariah (BPRS) pada tahun 1991 di Bandung dan PT. BPRS Heraukat di Nangroe Aceh Darussalam yang diprakarsai oleh Majelis Ulama Indonesia (MUI) melalui serangkaian lokakarya "Bunga Bank dan Perbankan" di Cisarua, Bogor pada tanggal 18 - 20 Agustus 1990. Setelah berdirinya BPRS yang diprakarsai MUI kemudian berkembang menjadi PT Bank Muamalat Indonesia (BMI) pada tahun 1991 dan mulai beroperasi tahun 1992. Pertumbuhan perbankan syariah masih lambat pada masa itu pada periode tahun 1992 - 1998 hanya ada satu unit bank syariah (Latumaerissa, 2011).

Perjalanan Bank Syariah sampai saat ini menunjukkan peningkatan yang pesat, sampai Desember 2020 tercatat jumlah Bank Umum Syariah (BUS) 14 bank, 20 Unit Usaha Syariah (UUS) dan 163 Bank Pembiayaan Rakyat Syariah (BPRS). Dari total asset yang dimiliki oleh industri perbankan syariah berjumlahRp. 545,4 triliun. (Otoritas Jasa Keuangan, 2021). Walaupun demikian tantangan perbankan syariah sangatlah besar, dilihat dari literasi masyarakat muslim Indonesia tentang bank syariah, indeks literasi bank syariah jauh di bawah indeks literasi perbankan umum yang sebesar $28,94 \%$. Sementara itu, tingkat inklusi keuangan syariah tak kalah rendah, hanya $8 \%$, sangat jauh jika dibandingkan indeks inklusi perbankan nasional yang sebesar 63\% (Rahman,2018).

Hal ini akan berimbas kepada kinerja bank syariah. Literasi yang rendah dapat mempengaruhi pendapatan atau bagi hasil nasabah itu sendiri, rendahnya pendapatan juga mempengaruhi perusahaan atau bank syariah untuk dapat membeli aktiva tetap demi berlangsungnya dan terus beroperasinya sebuah perusahaan dan menghasilkan sebuah barang maupun sebuah jasa, membayar hutang piutang dagang, membuat pengumpulan dan pengadaan persediaan kas perusahaan, melakukan investasi demi menjaga likuiditas perusahaan (Olivia, 2019).

Indikator sebuah perusahaan yang baik dapat dilihat dari kinerja keuangan. Kinerja keuangan merupakan rangkaian kegiatan menganalisis untuk melihat sejauh mana perusahaan telah menggunakan aturan pelaksanaan keuangan dengan baik dan benar. Pelaksaanan keuangan yang dimaksud yaitu kegiatan membuat laporan keuangan yang telah memenuhi standard ketentuan yang berlaku (Fahmi, 2014). Kinerja keuangan menyangkut aspek penghimpunan dana maupun penyaluran dana, yang diukur dari dua indikator, yaitu Return On Asset (ROA) dan Return On Equity (ROE). ROA merupakan rasio yang digunakan untuk mengukur kemampuan perusahaan melalui asset yang dimilikinya. Sementara ROE adalah rasio yang digunakan untuk mengukur kemampuan perusahaan dalam menghasilkan laba bersih bagi para investor. Kinerja keuangan juga merupakan suatu pacuan untuk menilai bagaimana suatu perusahaan mengelola sumber daya yang dimilikinya. Penelitian dari Dandung et al (Dandung et al., 2020) menunjukkan kinerja keuangan bank syariah (dari ROA, ROE dan LDR) lebih baik dari bank konvensional. Penelitian yang lain juga dari Vivin et al, (Vivin \& Wahono, 2017) menunjukkan kinerja keuangan bank syariah juga lebih baik dari bank konvensional.

Saat ini sektor ekonomi di dunia mengalami perubahan, hal ini dikarenakan kemajuan pada teknologi informasi yang menjadikan pertumbuhan inovasi yang terus menerus. Perubahan paradigma pada ekonomi dan bisnis yang semula berdasarkan pada labor based business (bisnis berdasarkan tenaga kerja) menuju kearah knowledge based business (bisnis berdasarkan pengetahuan) yang berbasiskan ilmu pengetahuan. Dalam manajemen berbasis pengetahuan ini modal 
konvensional yakni sumber daya keuangan dan asset fisik tidak terlalu penting, dibandingkan modal berbasis teknologi dan pengetahuan.

Intellectual capital (IC) adalah kajian penelitian baru yang mendapatkan perhatian cukup besar dari para ahli ekonomi, seiring dengan pertumbuhan ekonomi yang berbasis pada pengetahuan (knowledge-based economy) tersebut.(Ståhle et al., 2011). Salah satu upaya yang dilakukan perusahaan saat ini untuk menunjukkan kinerja dengan cara mengembangkan sumber daya manusia yang berkualitas, teknologi yang handal serta hubungan yang baik dengan pelanggan. Hal itu semua merupakan elemen dari Intelectual Capital.

Intellectual Capital (IC) mulai terkenal di Indonesia setelah adanya PSAK No. 19. Menurut PSAK 19, Aset tidak berwujud adalah aset non-moneter yang dapat di identifikasi dan tidak memiliki wujud fisik. PSAK 19 menyatakan bahwa aset tidak berwujud diakui jika, dan hanya jika: 1) ada manfaat yang diperoleh perusahaan dimasa yang akan datang dari aset tersebut, dan 2) biaya perolehan aset tersebut dapat diukur dengan andal. Persyaratan ini sulit dipenuhi, sehingga modal intelektual untuk tanggal tersebut tidak dapat dilaporkan dalam laporan keuangan. Kondisi ini menyulitkan para (calon) investor untuk dapat melakukan analisis dan penilaian terhadap prospek perusahaan dimasa yang akan datang berdasarkan potensi intelektual yang dimiliki(Ulum et al., 2014).

Kesulitan di dalam pengukuran intellectual capital (IC) secara langsung menyebabkan keberadaannya di dalam perusahaan sulit untuk diketahui. Pulic (1998) dalam (Ulum, 2013) mengatakan value added (VA) adalah indikator paling objektif untuk menilai keberhasilan bisnis dan menunjukkan kemampuan perusahaan dalam penciptaan nilai (value creation). VA didapat dari selisih antara output dan input. Dimana Output (OUT) menggambarkan revenue dan mencakup seluruh produk dan jasa yang dijual di pasar, sedangkan input (IN) mencakup seluruh beban yang digunakan dalam memperoleh revenue. Dalam hal ini beban karyawan (labour expenses) tidak termasuk dalam IN. Karena itu, aspek kunci dalam metode Pulic adalah memperlakukan tenaga kerja sebagai entitas penciptaan nilai (value creating entity).

Selanjutnya Pulic (1998) kemudian mengusulkan mengenai pengukuran secara tidak langsung terhadap intellectual capital (IC) dengan suatu ukuran untuk menilai efisiensi dari nilai tambah sebagai hasil dari kemampuan intelektual perusahaan, yaitu menggunakan Value Added Intellectual Coefficient (VAIC). Komponen utama dari VAIC dapat dilihat dari sumber daya perusahaan, yaitu physical capital (VACA-Value Added Capital Employed), human capital (VAHU- Value Added Human Capital), dan structural capital (STVA- Structural Capital Value Added).(Harianto \& Syafruddin, 2013).

Intellectual Capital (IC) pada perbankan syariah tidak jauh berbeda dengan model Pulic, perbedaannya terletak pada akun-akun yang digunakan untuk mengembangkan rumus VA. VA dalam model Pulic dikonstruksi dari total pendapatan, sementara dalam iB-VAIC, VA dalam perbankan syariah dikonstruksi dari aktivitas-aktivitas syariah. Maka untuk melihat VAIC pada perbankan syariah dipakai model yang dimodifikasi (Ulum, 2013). yakni iB-VAIC = iBVACA + IB-VAHU + iB-STVA, (iB menunjukkan pada kode Islamic Banking).

Banyak penelitian tentang intelcectual capital (IC) pada perusahaan maupun perbankan (terkhusus perbankan syariah). Penelitian Kartika (Kartika \& Hatane, 2013) bahwa VAHU tidak berpengaruh signifikan terhadap profitabilitas. STVA dan VACA berpengaruh dan memiliki arah pengaruh positif terhadap profitabilitas pada perusahaan perbankan yang ada di Bursa Efek Indonesia. Selanjutnya dalam Asmah (Karimah, 2016) menunjukkan bahwa intelectual capital (IC) berpengaruh pada kinerja keuangan perbankan syariah.

Berdasarkan fenomena diatas, peneliti tertarik untuk meneliti apakah intelectual capital (IC) berpengaruh terhadap terhadap kinerja keuangan pada bank syariah. Intellectual capital (IC) diukur dengan menggunakan model Pulic (1998) yang diadaptasi untuk perbankan syariah. Temua dari penelitian ini diharapkan dapat menjadi masukan yang berguna bagi perbankan Islam untuk mengelola investasi mereka di intelectual capital (IC).

\section{METODE PENELITIAN}

\subsection{Kerangka Dasar Penelitian}

Resources Based Theory yang menyatakan bahwa perbedaan sumber daya dan kemampuan perusahaan dengan perusahaan pesaing akan memberikan keunggulan kompetitif. Keunggulan kompetitif yang dimiliki perusahaan tersebut akan meningkatkan kinerja perusahaan itu sendiri. Santi et al (Lestari et al., 2018) meneliti hubungan intellectual capital yang diproksikan dengan VAIC menyatakan bahwa intellectual capital (IC) memiliki pengaruh positif terhadap kinerja bank syari'ah di Indonesia. Penelitian ini juga menyatakan bahwa intellectual capital (IC) tahun lalu memiliki pengaruh positif terhadap kinerja bank syari'ah pada tahun- tahun berikutnya.

Persaingan yang ketat antar bank umum syariah dengan bank konvensional, membuat perbankan syariah harus meningkatkan strategi pada masyarakat dalam mempromosikan produk dan layanan perbankan syariah. Tantangan terbesar adalah meningkatkan literasi masyarakat tentang perbankan syariah, karena walaupun masyarakat Indonesia mayoritas muslim namun minim tetangn literasi keuangan syariah. Manajemen bank syariah perlu menggerakkan seluruh sumber daya yang ada untuk meningkatkan pangsa pasar dan kinerjanya agar dapat bersaing dengan bank konvensional yang ada di Indonesia. Pengembangan perbankan syari-ah ini harus didukung oleh penerapan sistem manajemen yang berdasarkan pada pengetahuan dalam sistem operasionalnya. Penggunaan ilmu pengetahuan dan teknologi akan membuat perusahaan menggunakan sumber daya lainnya secara efisien dan ekonomis sehingga dapat memberikan keunggulan pada dunia perbankan syariah di Indonesia. 
Kerangka dasar penelitian yang diajukan adalah dasar hubungan dari variabel independen (bebas) terhadap variabel dependent (terikat). Dalam peneltian ini akan dilihat pengaruh intellectual capital (IC) yang dimodifikasi dalam perbankan syariah sebagai variabel independent yang didasarkan oleh Value Added Capital Imployed (iB-VACA), Value Added Human Capital (iB-VAHU) dan Structural Capital Value Added (iB-STVA) terhadap kinerja keuangan sebagai variabel dependent. Untuk lebih mempermudah, maka dapat dihat pada gambar dibawah ini:

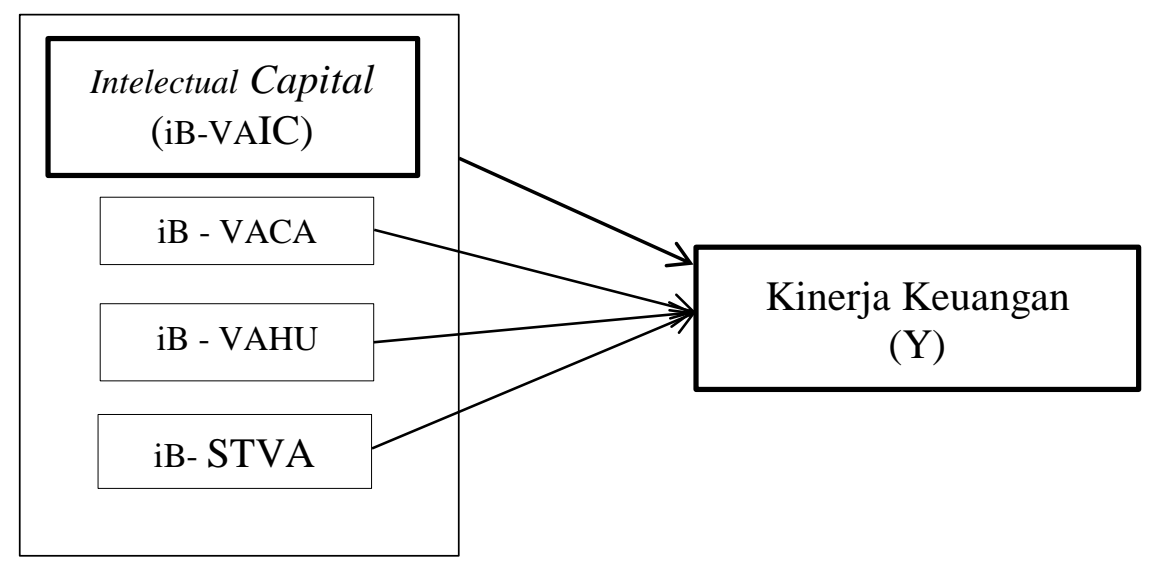

Gambar 1. Kerangka Konseptual Penelitian

Berdasarkan kerangka pemikiran diatas dapat disimpulkan hipotesis sebagai berikut:

$\mathrm{H}_{1}$ : iB-VAIC berpengaruh positif terhadap kinerja keuangan

$\mathrm{H}_{2}$ : iB-VACA berpengaruh positif terhadap kinerja keuangan

$\mathrm{H}_{3}$ : iB-VAHU berpengaruh positif terhadap kinerja keuangan

$\mathrm{H}_{4}$ : iB-STVA berpengaruh positif terhadap kinerja keuangan

\subsection{Populasi dan Sampel}

Populasi penelitian ini adalah laporan keuangan tahun dari tahun 2013 sampai 2020 secara rutin (tri wulan) oleh Bank Negara Indonesia (BNI) Syariah. Dalam penelitian ini digunakan metode sensus, artinya seluruh populasi dijadikan sebagai objek penelitian.

\subsection{Variabel Penelitian}

Variabel Variabel dependet adalah kinerja keuangan dan independen yakni intellectual capital (IC). intellectual capital (IC) khusus untuk perbankan syariah yang diberi nama IB-VAIC (Islamic Banking Value Added Intellectual Coefficient). Perumusan ini merupakan modifikasi dari penilaian kinerja IC pada umumnya. Jika penilaian IC pada umumnya hanya dapat digunakan untuk mengukur pada perusahaan, maka IB-VAIC ini dapat digunakan untuk mengukur kinerja bank syariah.

Ada beberapa indikator untuk menghitung IB-VAIC, yaitu :

1. IB-VACA (Islamic Banking Value Added Capital Emloyed). VACA merupakan suatu indikator yang digunakan untuk menunjukan nilai tambah (VA) yang diperoleh dengan adanya jumlah ekuitas.

$$
\mathrm{IB}-\mathrm{VACA}=\frac{V A}{C E}
$$

Keterangan :

1) VA : value added

2) CE : capital employed atau dana yang tersedia (Ekuitas)

2. IB-VAHU (Islamic Banking Value Added Human Capital). VAHU digunakan untuk mengukur nilai tambah (VA) yang dihasilkan dengan dana yang dikeluarkan untuk tenaga kerja.

$$
\mathrm{IB}-\mathrm{VAHU}=\frac{V A}{H U}
$$

Keterangan :

1) VA : value added

2) HU : human capital atau beban karyawan

3. Menghitung IB-STVA (Islamic Banking Structural Capital Value Added). STVA digunakan untuk mengukur jumlah SC yang dibutuhkan untuk menghasilkan satu rupiah dari IB-VA.

$$
\text { IB-STVA }=\frac{S C}{V A}
$$

Keterangan :

1) VA : value added 
2) SC : Structural Capital (modal structural) yang diperoleh dari VA - HU

4. IB-VAIC (Islamic Banking Value Added Intellectual Coefficient). VAIC merupakan indikator yang digunakan untuk menilai kemampuan intelektual suatu organisasi/perusahaan.

$$
\mathrm{IB}-\mathrm{VAIC}=\mathrm{VACA}+\mathrm{VAHU}+\mathrm{STVA}
$$

\subsection{Teknik Analaisis Data}

Pada penelitian ini akan digunakan metode Structural Equation Modeling (SEM) yang berbasis varian atau Partial Least Square (PLS) dengan melibatkan beberapa variabel seperti iB-VACA, iB-VAHU, iB- STVA dan kinerja keuangan. SEM merupakan teknik analisis multivarian yang dikembangkan guna menutupi keterbatasan yang dimiliki oleh model analisis sebelumnya.

\section{HASIL DAN PEMBAHASAN}

\subsection{Evaluasi Model Pengukuran (Uji Outer Model)}

Adapun model pengukuran untuk uji validitas dan reabilitas, koefisien determinasi model dan koefisien jalur untuk permodelan persamaan, dapat dilihat pada gambar berikut:

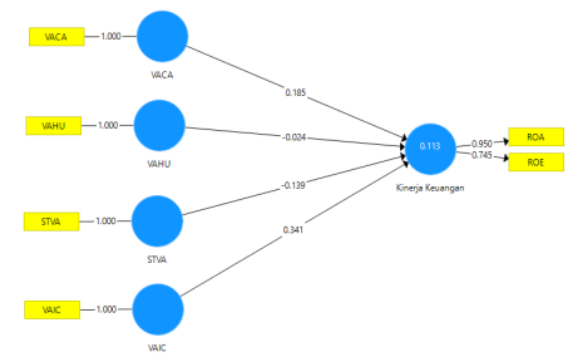

Gambar 2. Tampilan Hasil PLS Algorithm Uji Outer Model

\subsubsection{Convergent Validity}

Convergent validity dari measurement model dapat dilihat dari korelasi antara skor indikator dengan skor skor variabelnya. Indikator dianggap valid jika memiliki nilai AVE diatas 0,5.

Tabel 1. AVE dan Communality

\begin{tabular}{ccc}
\hline & AVE & Communality \\
\hline Kinerja Keuangan & 0,728 & 0,938 \\
VAIC & 1,000 & 1,000 \\
VACA & 1,000 & 1,000 \\
VAHU & 1,000 & 1,000 \\
STVA & 1,000 & 1,000 \\
\hline
\end{tabular}

Berdasarkan pengujian model pengukuran yang terlihat pada gambar 2 dan tabel dapat dilihat bahwa oading factor dan communality di atas 0,5 baik pada Kinerja keuangan, VAIC, VACA, VAHU dan STVA. Maka dapat disimpulkan bahwa konstruk mempunyai convergent validity yang baik.

\subsubsection{Discriminate Validity}

Pengujian discriminate validity dilakukan untuk membuktikan apakah indikator pada suatu konstruk akan mempunyai loading factor terbesar pada konstruk yang dibentuknya dari pada loading factor dengan konstruk yang lain.

Tabel 2. Cross loading

\begin{tabular}{lccccc}
\hline & Kinerja Keuangan & VACA & VAHU & STVA & VAIC \\
\cline { 3 - 6 } VACA & 0,153 & $\mathbf{1 , 0 0 0}$ & 0,290 & 0,363 & 0,077 \\
VAHU & 0,192 & 0,290 & $\mathbf{1 , 0 0 0}$ & 0,552 & 0,703 \\
STVA & 0,052 & 0,363 & 0,552 & $\mathbf{1 , 0 0 0}$ & 0,401 \\
VAIC & 0,282 & 0,077 & 0,703 & 0,401 & $\mathbf{1 , 0 0 0}$ \\
ROA & $\mathbf{0 , 9 5 0}$ & 0,155 & 0,184 & 0,093 & 0,319 \\
ROE & $\mathbf{0 , 7 4 5}$ & 0,095 & 0,139 & $-0,095$ & 0,101 \\
\hline
\end{tabular}

Berdasarkan hasil uji discriminate validity pada tabel 2 di atas, menunjukkan nilai cross loading juga menunjukkan adanya discriminate validity yang baik, oleh karena nilai korelasi indikator terhadap konstruknya lebih tinggi dibandingkan nilai kolerasi indikator dengan konstruk lainnya. 


\subsubsection{Composite Reliability dan Cronbach's Alpha}

Disamping uji validitas konstruk, dilakukan juga uji reliabilitas konstruk yang diukur dengan composite reliability dan cronbach's alpha dari blok indikator yang mengukur konstruk. Berikut ini adalah hasil pengujian composite reliability dan cronbach's alpha dari SmartPLS:

Tabel 3. Composite reliability dan Cronbach's alpha

\begin{tabular}{ccc}
\hline & Composite reliability & Cronbach's alpha \\
\hline Kinerja Keuangan & 0,841 & 0,665 \\
VAIC & 1,000 & 1,000 \\
VACA & 1,000 & 1,000 \\
VAHU & 1,000 & 1,000 \\
STVA & 1,000 & 1,000 \\
\hline
\end{tabular}

Konstruk dinyatakan reliabel jika memiliki nilai composite reliability di atas 0,7 dan cronbach's alpha 0,7 . Dari hasil output SmartPLS di atas semua konstruk memiliki nilai composite reliability di atas 0,7 dan cronbach's alpha 0,7. Jadi dapat disimpulkan bahwa konstruk memiliki reliabilitas yang baik.

\subsection{Evaluasi Model Pengukuran ( Uji Inner Model)}

Model struktural dalam PLS dievaluasi dengan menggunakan $R$-Square untuk variabel dependen dan nilai koefisien path untuk variabel independen yang kemudian dinilai signifikansinya berdasarkan nilai $t$-statistic setiap path. Adapun model struktural penelitian ini dapat dilihat pada gambar berikut:

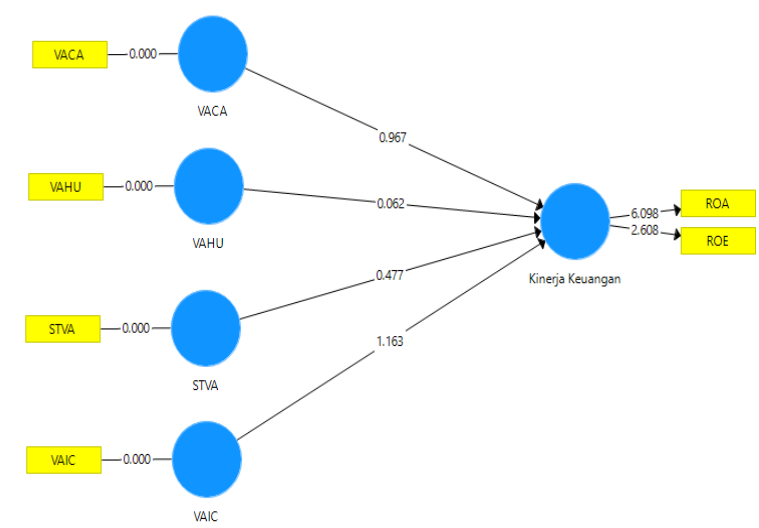

Gambar 3. Tampilan Hasil PLS Boothstrapping

Untuk menilai signifikansi model prediksi dalam pengujian model struktural, dapat dilihat dari nilai $t$-statistic antara variabel independen ke variabel dependen dalam tabel Path Coefficient pada output SmartPLS dibawah ini:

Tabel 4. Path Coefficients (Mean, STDEV, T-Statistic)

\begin{tabular}{lcccc}
\hline & $\begin{array}{c}\text { Original } \\
\text { Sample }\end{array}$ & Sample Mean & $\begin{array}{c}\text { Standart } \\
\text { Deviation }\end{array}$ & T-Statistic \\
\hline VAIC => Kinerja Keuangan & 0,341 & 0,325 & 0,305 & 1,119 \\
VACA => Kinerja Keuangan & 0,185 & 0,201 & 0,199 & 0,927 \\
VAHU => Kinerja Keuangan & $-0,024$ & 0,087 & 0,396 & 0,062 \\
STVA => Kinerja Keuangan & $-0,139$ & $-0,086$ & 0,307 & 0,451 \\
\hline
\end{tabular}

Pengujian Hipotesis Pertama $\left(\mathrm{H}_{1}\right)$ : iB-VAIC berpengaruh positif terhadap kinerja keuangan

Dari tabel 4 di atas dapat dilihat nilai original sample VAIC adalah sebesar 0,341. Dengan signifikansi $5 \%$ maka nilai $t$ table sebesar 0,361. Dapat dilihat pada tabel nilai t-statistic dari VAIC sebesar 1,119 lebih besar dari nilai t-tabel. Nilai original sample positif mengindikasikan bahwa VAIC berpengaruh positif terhadap kinerja keuangan. Berdasarkan hasil regresi tersebut dapat disimpulkan bahwa hipotesis pertama diterima.

Hal ini sesuai dengan hipotesis yang menyatakan bahwa Intellectual Capital yang diukur oleh VAIC berpengaruh positif signifikan terhadap kinerja keuangan. Oleh karena itu, semakin tinggi VAIC, maka kinerja keuangan semakin meningkat. Kondisi ini terjadi karena VAIC yang semakin meningkat, maka Bank BNI Syariah sudah mengelola sumber daya dan juga modalnya dengan baik sehingga keuangan yang ada di Bank BNI Syariah tersebut meningkat.

Hasil penelitian ini sejalan dengan penelitian Dianing Ratna Wijayani (Wijayani, 2017) yang menyatakan bahwa VAIC berpengaruh signifikan dan positif terhadap kinerja keuangan suatu perusahaan. Tetapi hasil penelitian ini tidak 
sejalan dengan penelitian Wijayanti (Wijayanti, 2012) yang membuktikan bahwa Intellectual Capital yang diukur dengan VAIC tidak berpengaruh signifikan terhadap kinerja keuangan.

\section{Pengujian Hipotesis Kedua: iB-VACA berpengaruh positif terhadap kinerja keuangan}

Pengujian kedua dilakukan untuk melihat apakah VACA berpengaruh positif terhadap kinerja keuangan. Hasil pengujian dapat dilihat dari tabel 4.4 di atas, VACA memperoleh nilai original sample sebesar 0,185 dengan nilai $t$-statistic 0,927. Nilai dari $t$-statistic lebih besar dari nilai t-tabelnya yaitu 0,361. Hal ini berarti VACA berpengaruh positif terhadap kinerja keuangan dengan tingkat signifikansi 5\%. Berdasarkan hasil pengujian tersebut dapat disimpulkan bahwa hipotesis kedua diterima.

Berdasarkan hasil pengujian pada hipotesis kedua menunjukkan bahwa VACA juga berpengaruh terhadap kinerja keuangan. Dari ketiga variabel penyusun VAIC, VACA memiliki pengaruh yang dominan. Hal ini dikarenakan Bank BNI Syariah mampu untuk mengelola ekuitas yang ada sehingga kinerja dari keuangan meningkat.

Hal ini sesuai dengan hasil penelitian sebelumnya yang dilakukan Deep et all (Deep \& Narwal, 2014) menemukan bahwa VACA adalah salah satu yang terlihat memiliki dampak besar pada profitabilitas perusahaan selama periode studi. Hasil menunjukkan bahwa investor India hanya mempertimbangkan pengungkapan keuangan perusahaan mengenai keputusan investasi mereka. Studi ini memberikan pengetahuan yang berguna bagi para peneliti dan manajer mengenai pengungkapan modal intelektual dan hubungannya dengan kinerja keuangan.

Akan tetapi penelitian ini tidak sesuai dengan penelitian yang dilakukan olehYudawisastra (Yudawisastra et al., 2018), mengatakan dalam penelitiannya bahwa VACA tidak memiliki pengaruh yang signifikan terhadap kinerja keuangan. Kesimpulan menunjukkan bahwa tingkat kontribusi yang tinggi terhadap tenaga kerja perusahaan akan membutuhkan dana yang lebih banyak untuk mencapai kinerja keuangan yang baik.

\section{Pengujian Hipotesis Ketiga $\left(\mathrm{H}_{3}\right)$ : iB- VAHU berpengaruh positif terhadap kinerja keuangan}

Pengujian hipotesis ketiga ditujukan untuk melihat pengaruh VAHU terhadap kinerja keuangan. Berdasarkan hasil pengujian, VAHU memperoleh nilai original sample sebesar -0,024 dengan nilai $t$-statistic 0,062 lebih kecil dari t-tabel yaitu 0,361 yang berarti variabel VAHU tidak berpengaruh terhadap kinerja keuangan dengan signifikansi 5\%. Dari hasil regresi hipotesis tersebut dapat simpulkan bahawa hipotesis ketiga tidak diterima.

Artinya di dalam Bank BNI Syariah nilai kontribusi yang diberikan dalam setiap satu rupiah investasi pada human capital tidak berpengaruh untuk suatu kinerja keuangan. Hasil ini juga telah menjawab hipotesis kedua dimana VACA berpengaruh signifikan terhadap kinerja keuangan. Adanya kemungkinan bahwa Bank BNI Syariah lebih cenderung menggunakan physical capital, sehingga dapat dikatakan capital employed yang dimiliki oleh perusahaan dapat memiliki pengaruh terhadap kinerja keuangan. Penelitian ini juga menunjukkan bahwa modal yang digunakan merupakan nilai aset yang berkontribusi pada kemampuan perusahaan untuk menghasilkan pendapatan. Sehingga apabila modal yang digunakan suatu perusahaan dalam jumlah yang relatif besar maka mengakibatkan total aset perusahaan tersebut juga relatif besar.

Ini sejalan dengna penelitian yang dilakukan Sidarta et all (Sidharta \& Affandi, 2016) dengan nilai T sama dengan 0,070. Hasil Q nilainya lebih kecil dari taraf signigikansi $0,5 \%$. Sehingga variabel VAHU tidak signifikan terhadap kinerja keuangan. Namun hasil ini tidak sejalan yang dilakukan dengan penelitian Lipunga (Lipunga, 2014) yang menunjukkan bahwa VAHU berpengaruh positif terhadap kinerja kerja.

\section{Pengujian Hipotesis Keempat $\left(\mathrm{H}_{4}\right)$ : iB-STVA berpengaruh positif terhadap kinerja keuangan}

Pengujian hipotesis keempat ditujukan untuk melihat pengaruh STVA terhadap kinerja keuangan. Berdasarkan hasil pengujian, STVA memperoleh nilai original sample sebesar -0,139 dengan nilai $t$-statistic 0,451 lebih besar dari ttabelnya yaitu 0,361. Oleh karena nilai original sample dari STVA bernilai negatif maka STVA berpengaruh negatif terhadap kinerja keuangan. Hal ini menunjukkan bahwa jika nilai dari STVA di tingkatkan, maka kinerja keuangan akan menurun. Begitupun sebaliknya, jika nilai STVA diturunkan maka kinerja keuangan akan meningkat. Dari hasil regresi hipotesis tersebut dapat simpulkan bahwa hipotesis keempat tidak dapat diterima.

Hasil pengujian hipotesis keempat menunjukkan bahwa kinerja keuangan. Hal ini menunjukkan bahwa Bank BNI Syariah belum berhasil mengelolah structural STVA berpengaruh negative terhadap capitalnya seperti meningkatkan sistem operasional perusahaan, menjaga budaya perusahaan dan mengolah intellectual property secara efektif. Semakin tinggi nilai STVA yang dikembangkan maka semakin rendah pula nilai kinerja keuangan yang ada di dalam Bank BNI Syariah. Penelitian ini sesuai dengan Girma (Girma, 2017) yang menunjukkan bahwa STVA bahwa secara keseluruhan STVA berkorelasi negatif terhadap kinerja perusahaan. Penelitian mengindikasikan bahwa hubungan antara efisiensi structural capital dari sumber daya utama perusahaan yaitu profitability secara umum terbatas dan tidak konsisten

\section{KESIMPULAN}

Penelitian ini memberikan bukti empiris mengenai pengaruh Intellectual Capital yang diukur melalui iB-VAIC (iBVACA, iB-VAHU dan iB-STVA) terhadap kinerja keuangan. Penelitian ini menggunakan sampel 32 responden, yang merupakan laporan keuangan pertriwulan dari Bank BNI Syariah dari tahun 2013 sampai 2020. Untuk Vallue Added Intellectual Coefficient (iB-VAIC) berpengaruh terhadap kinerja keuangan. Dimana iB-VAIC yang efektif dapat meningkatkan nilai dari kinerja keuangan. Semakin baik nilai dan penggunaan Intellectual Capital juga akan meningkat 
suatu kinerja perusahaan. Value Added Capital Employed (iB-VACA) berpengaruh terhadap kinerja keuangan. Hal ini mengindikasikan bahwa nilai ekuitas perusahaan yang relatif besar dapat meningkatkan kemampuan perusahaan dalam memperoleh pendapatan. Dengan kata lain, nilai ekuitas perusahaan berkontribusi pada kemampuan perusahaan dalam meningkatkan kinerja keuangan perusahaan. Perusahaan telah berhasil meningkatkan produktivitas aset yang ada didalamnya, dimana total aset tersebut merupakan bagian dari intellectual capital yang merupakan intangible asset yang memiliki peran penting dalam kemajuan kinerja keuangan perusahaan. Value Added Human Capital (iB-VAHU) tidak berpengaruh terhadap kinerja keuangan. Hal ini memungkinkan bahwa Bank BNI Syariah lebih cenderung menggunakan Physical Capital daripada Human Capital. Dengan kata lain, modal yang dimiliki oleh Bank BNI Syariah lebih memilki pengaruh yang signifikan dibandingkan nilai human capital yang dimiliki. Structural Capital Value Added (iB-STVA) memiliki pengaruh negatif terhadap kinerja keuangan. Dalam hal ini, semakin tinggi nilai structural capital yang diberikan oleh perusahaan maka semakin rendah tingkat kinerja keuangan perusahaan. Sebaliknya, semakin rendah nilai structural capital rendah maka nilai dari kinerja keuangan perusahaan tinggi. Hal ini mengindikasikan bahwa structural capital belum mampu memenuhi proses rutinitas perusahaan dalam menghasilkan kinerja yang optimal tanpa diiringi pengelolaan yang baik seperti pengelolaan sistem informasi, prosedur, database yang akan menghambat produktivitas dalam menghasilkan nilai tambah.

\section{UCAPAN TERIMAKASIH}

Kami ucapkan banyak terima kasih kepada Sekolah Tinggi Agama Islam (STAI) Syekh H. Abdul Halim Hasan Al Ishlahiyah Binjai yang telah membantu dalam penelitian ini.

\section{REFERENCES}

Dandung, M.E., Amtiran, P. Y., \& Ratu, M. (2020). Analisis Perbandingan Kinerja Keuangan Perbankan Konvensional Dan Perbankan Syariah. Journal of Management: Small and Medium Enterprises (SMEs), 11(1), 65-82. https://doi.org/10.35508/jom.v11i1.2319

Deep, R., \& Narwal, K. P. (2014). Intellectual Capital and its Association with Financial Performance: A Study of Indian Textile Sector. Int. J. Manag. Bus. Res, 4(1), 43-54.

Fahmi, I. (2014). Analisis Laporan Keuangan. Alfabeta.

Girma, B. (2017). Intellectual Capital Efficiency and Its Impact on Financial Performances of Ethiopian Commercial Banks. Research Journal of Finance and Accounting, 8(8), 17-31.

Harianto, N., \& Syafruddin, M. (2013). Pengaruh Modal Intelektual Terhadap Kinerja Bisnis Bank Umum Syariah (Bus) Di Indonesia. Diponegoro Journal of Accounting, O(0), 408-417.

Karimah, A. (2016). PENGARUH INTELLECTUAL CAPITAL TERHADAP KINERJA KEUANGAN PERBANKAN SYARIAH (Studi Pada Bank Umum Syariah, BNI Syariah, BRI Syariah, Bank Panin Syariah Periode 2011 - 2014) SKRIPSI (Issue 1). Universitas Islam Negeri Syarif Hidayatullah.

Kartika, M., \& Hatane, S. E. (2013). Pengaruh Intelectual Capital Pada Profitabilitas Perusahaan Perbankan Yang Terdaftar Di Bursa Efek Indonesia Pada Tahun 2007-2011. Business Accounting Review, 1(2), 14-25.

Latumaerissa, J. (2011). Bank dan Lembaga Keuangan Lain. Salemba Empat.

Lestari, S. D., Paramu, H., \& Sukarno, H. (2018). Pengaruh Intellectual Capital Terhadap Kinerja Keuangan Perbankan Syari'Ah Di Indonesia. EKUITAS (Jurnal Ekonomi Dan Keuangan), 20(3), 346-366. https://doi.org/10.24034/j25485024.y2016.v20.i3.64

Lipunga, A. M. (2014). Intellectual Capital Performance of the Commercial Banking Sector of Malawi. International Journal of Business and Management, 10(1), 210-222. https://doi.org/10.5539/ijbm.v10n1p210

Olivia, H. (2019). Penerapan Analisis Roi (Retrun On Investment) Untuk Memprediksi Pendapatan Perusahaan. Kitabah, 3(2), 211218.

Otoritas Jasa Keuangan. (2021). Perkembangan Bank Syariah 2020. https://www.ojk.go.id

Rahman, A. (2018). Literasi Rendah Jadi Tantangan Utama Bank Syariah. Bisnis.Com.

Sidharta, I., \& Affandi, A. (2016). The empirical study on intellectual capital approach toward financial performance on rural banking sectors in Indonesia. International Journal of Economics and Financial Issues, 6(3), 1247-1253.

Ståhle, P., Ståhle, S., \& Aho, S. (2011). Value added intellectual coefficient (VAIC): a critical analysis. Journal of Intellectual Capital, 12(4), 531-551. https://doi.org/10.1108/14691931111181715

Ulum, I. (2013). Model Pengukuran Kinerja Intellectual Capital Dengan Ib-Vaic Di Perbankan Syariah. Inferensi, $7(1)$, 185. https://doi.org/10.18326/infs13.v7i1.185-206

Ulum, I., Ghozali, I., \& Purwanto, A. (2014). Intellectual Capital Performance of Indonesian Banking Sector: A Modified VAIC (MVAIC) Perspective. Asian Journal of Finance \& Accounting, 6(2), 103. https://doi.org/10.5296/ajfa.v6i2.5246

Vivin, Y. A., \& Wahono, B. (2017). Analisis Perbandingan Kinerja Keuangan Bank Umum Syariah dengan Bank Umum Konvensional di Indonesia. E-Jurnal Riset Manajemen, 77-97.

Wijayani, D. R. (2017). PENGARUH INTELLECTUAL CAPITAL TERHADAP KINERJA KEUANGAN PERUSAHAAN PUBLIK DI INDONESIA (Studi Empiris Pada Perusahaan Manufaktur di BEI 2012-2014). Jurnal Riset Akuntansi Dan Bisnis Airlangga, 2(1), 97-116. https://doi.org/10.31093/jraba.v2i1.23

Wijayanti. (2012). Pengaruh Intellectual Capital Terhadap Harga Saham Melalui Kinerja Keuangan Pada Perusahaan Perbankan Yang Terdaftar di Bursa Efek Indonesia (BEF). Jurnal Akuntansi Dan Keuangan, 7.

Yudawisastra, H. G., Manurung, D. T. H., \& Husnatarina, F. (2018). Relationship between value added capital employed, value added human capital, structural capital value added and financial performance. Investment Management and Financial Innovations, 15(2), 222-231. https://doi.org/10.21511/imfi.15(2).2018.20 